\title{
INFLUENCE OF ENTREPRENEURSHIP ORIENTATION AND INTERNAL RESOURCES ON BUSINESS PERFORMANCE OF MSMES (STUDY ON MELINJO EMPING BUSINESS ACTORS IN POJOK VILLAGE, NGANTRU SUBDISTRICT, TULUNGAGUNG REGENCY)
}

\author{
Suheri $^{1^{*}}$, Budi Setiawan ${ }^{2}$, Hery Toiba $^{2}$ \\ ${ }^{1}$ Master of Agribusiness Study Program, Faculty of Agriculture, Brawijaya University, Malang, Indonesia \\ ${ }^{2}$ Lecturer of Faculty of Agriculture, Brawijaya University, Malang, Indonesia \\ *corresponding author: suheriofficial2105@gmail.com
}

\begin{abstract}
The purpose of this study is (1) describing and analyzing the significance of the simultaneous influence of entrepreneurial orientation and internal resources on the business performance of home industry emping melinjo in Pojok Village, (2) describing and analyzing the significance of the influence of entrepreneurial orientation on the business performance of MSMEs home industry emping melinjo in Pojok Village, (3) describing and analyzing the significance of the influence of internal resources on the business performance of MSMEs home industry emping melinjo in The Corner Village. This research was conducted in Pojok Village, Ngantru Subdistrict, Tulungagung Regency with a sample number of 55 people. The results of the study There is a significant influence simultaneously entrepreneurial orientation and internal resources on the business performance of MSMEs home industry emping melinjo in The Corner Village, Ngantru Subdistrict, Tulungagung Regency. There is a positive and significant influence of entrepreneurial orientation on the business performance of MSMEs home industry emping melinjo in Pojok Village, Ngantru Subdistrict, Tulungagung Regency. There is a positive and significant influence of internal resources on the business performance of MSMEs home industry emping melinjo in Pojok Village, Ngantru Subdistrict, Tulungagung Regency.
\end{abstract}

Keywords: Entrepreneurial Orientation, Internal resources, Business Performance

http://dx.doi.org/10.21776/ub.agrise.2021.021.4.2

Received 12 April 2021

Accepted 11 October 2021

Available online 31 October 2021

\section{INTRODUCTION}

The entrepreneurial orientation itself has the understanding as the orientation of the company's strategy in entrepreneurship to gain a competitive advantage with indicators of decision making, practice and methods (Risnawati and Noermijati, 2008), the tendency of individuals to innovate, proactive and willing to take risks to start or manage a business (Ginsberg, 2011). Entrepreneurial orientation is a corporate value system that determines the direction of motion or strategy of the company, has 5 (five) dimensions, namely: innovativeness, risk-taking, proactiveness, competitive aggressiveness, and autonomy (Lumpkin and Dess, 2006).

Meanwhile, Internal Resources is the owner of various assets of the company (including MSMEs) which is a source of strength of the company internally to run the company to achieve profit. Internal resources include all financial, physical, human, and corporate culture assets used by the company to develop, create, and sell its products or services (Kuncoro, 2018).

Explanation of theoretical and empirical conception of the interrelationship of entrepreneurial orientation and internal resources with business performance (no exception to the business performance of MSMEs) as explained

CITATION: Suheri, S., Setiawan, B., Toiba, H., (2021). Influence of Entrepreneurship Orientation and Internal Resources on Business Performance of MSMEs (Study on Melinjo Emping Business Actors in Pojok Village, Ngantru Subdistrict, Tulungagung Regency), Agricultural Socio-Economics Journal, 21(4), 267-276 DOI: http://dx.doi.org/10.21776/ub.agrise.2021.021.4.2 
above, provides an understanding that to be able to survive and have a competitive advantage of course MSMEs should not only focus on product quality alone. MSMEs should also be able to apply entrepreneurial orientation while optimizing the utilization of internal resources owned to realize the better business performance of MSMEs. That is, the good business performance of MSMEs will certainly open the opportunity for MSMEs to be superior in competition for the market when compared to other competitors, no exception the existence of MSMEs located in the administrative area of Tulungagung Regency.

However, the existence of MSMEs in the Tulungagung regency is also inseparable from the classic problems as happened to other MSMEs that make the development of MSMEs less optimal. The main problem that occurs is the low quality of human resources (HR), both from the point of view of knowledge and skills owned to have an impact on the management of MSMEs that are less qualified and impressed as a business entity. The obstacles faced by MSMEs in Tulungagung regency are also related to capital, marketing distribution, and the low absorption capability of information technology. In terms of capital, the average MSMEs have difficulty in managing capital turnover due to the limited amount of business capital owned. While this MSMEs every day must continue to do production even if they do not get orders or sales to customers. Related to marketing distribution, the low quality of human resources of MSMEs makes it less able to segment the market so that it does not have the right marketing strategy. These problems are also common in MSMEs home industry emping melinjo in Pojok Village, Ngantru Subdistrict, Tulungagung Regency.

\section{RESEARCH METHODS}

This research method uses descriptive quantitative approaches with survey methods. This research was conducted in Pojok Village, Ngantru Subdistrict, Tulungagung Regency, the determination of samples used is purposive sampling nonprobability technique, with Consideration (1). The home industry emping melinjo businesses that have been running the business for at least 10 (ten) years (2). Melinjo home industry emping business that has been registered in the Office of Cooperatives and MSMEs Tulungagung Regency. Based on these considerations, the number of samples in each Ngadirejo village is as many as 47 people and Sumber Hamlet as many as 8 people, so the total number of research samples is 55 people.

Data collection in this study is through questionnaire techniques and documentation. The instruments in this study were questionnaires with
Likert 1-5 scale measurements that have been tested for the validity of Pearson Product Moment and Alpha Cronbach reliability tests. The data analysis method in this study used multiple linear regression statistics, dominant coefficient test $\left(\mathrm{R}^{2}\right)$, and continued with hypothesis testing with F-test and ttest.

\section{RESULTS AND DISCUSSION}

\section{Research Instrument Test Results}

Testing of research instruments in the form of validity tests and questionnaire reliability tests were conducted on a research sample of 55 people.

Questionnaire validity test with the number of respondents (n) 55 people at the level of significance $(\alpha)=5 \%$, degree of freedom value (d.f) with the formula $n-2$ is $55-2=53$. Thus the table value of product-moment is 0.261 .

Table 1. Questionnaire Validity Test Results

\begin{tabular}{|c|c|c|c|c|c|}
\hline Variabele & Grain & $\mathbf{r}_{\mathrm{xy}}$ & $r_{\text {tabel }}$ & $\underset{\left(r_{x y} \geq r_{\text {tabece }}\right)}{\text { Critia }}$ & Decision \\
\hline \multirow{22}{*}{$\begin{array}{l}\text { Business Performance } \\
\text { of MSMEs (Y) }\end{array}$} & $\mathrm{Y}_{1}$ & 0,650 & $\overline{0,261}$ & 0,650 & Valid \\
\hline & $\mathrm{Y}_{2}$ & 0,450 & 0,261 & 0,450 & Valid \\
\hline & $\mathrm{Y}_{3}$ & 0,546 & 0,261 & 0,546 & Valid \\
\hline & $\mathrm{Y}_{4}$ & 0,845 & 0,261 & 0,845 & Valid \\
\hline & $\mathrm{Y}_{5}$ & 0,847 & 0,261 & 0,847 & Valid \\
\hline & $\mathrm{Y}_{6}$ & 0,801 & 0,261 & 0,801 & Valid \\
\hline & $\mathbf{Y}_{7}$ & 0,600 & 0,261 & 0,600 & Valid \\
\hline & $\mathrm{Y}_{8}$ & 0,710 & 0,261 & 0,710 & Valid \\
\hline & $\mathrm{Y}_{9}$ & 0,837 & 0,261 & 0,837 & Valid \\
\hline & $\mathrm{Y}_{10}$ & 0,742 & 0,261 & 0,742 & Valid \\
\hline & $\mathrm{Y}_{11}$ & 0,830 & 0,261 & 0,830 & Valid \\
\hline & $\mathrm{Y}_{12}$ & 0,799 & 0,261 & 0,799 & Valid \\
\hline & $\begin{array}{l}112 \\
Y_{13}\end{array}$ & 0,691 & 0,261 & 0,691 & Valid \\
\hline & $\mathrm{Y}_{14}$ & 0,795 & 0,261 & 0,795 & Valid \\
\hline & $\mathrm{Y}_{15}$ & 0,520 & 0,261 & 0,520 & Valid \\
\hline & $\mathrm{Y}_{16}$ & 0,611 & 0,261 & 0,611 & Valid \\
\hline & $\mathrm{Y}_{17}$ & 0,774 & 0,261 & 0,774 & Valid \\
\hline & $\mathrm{Y}_{18}$ & 0,754 & 0,261 & 0,754 & Valid \\
\hline & $\mathrm{Y}_{19}$ & 0,619 & 0,261 & 0,619 & Valid \\
\hline & $\mathrm{Y}_{20}$ & 0,661 & 0,261 & 0,661 & Valid \\
\hline & $\mathrm{Y}_{21}$ & 0,656 & 0,261 & 0,656 & Valid \\
\hline & $\mathrm{Y}_{22}$ & 0,696 & 0,261 & 0,696 & Valid \\
\hline \multirow{10}{*}{$\begin{array}{l}\text { Entrepreneurial } \\
\text { Orientation (X1) }\end{array}$} & $\mathrm{X}_{1.1}$ & 0,730 & 0,261 & 0,730 & Valid \\
\hline & $\mathrm{x}_{1.2}$ & 0,567 & 0,261 & 0,567 & Valid \\
\hline & $\mathrm{X}_{1.3}$ & 0,647 & 0,261 & 0,647 & Valid \\
\hline & $\mathrm{X}_{1.4}$ & 0,804 & 0,261 & 0,804 & Valid \\
\hline & $\mathrm{X}_{1.5}$ & 0,804 & 0,261 & 0,804 & Valid \\
\hline & $\mathrm{X}_{16}$ & 0,750 & 0,261 & 0,750 & Valid \\
\hline & $\mathrm{X}_{1.7}$ & 0,714 & 0,261 & 0,714 & Valid \\
\hline & $\begin{array}{l}2.7 \\
\mathrm{X}_{1.8}\end{array}$ & 0,658 & 0,261 & 0,658 & Valid \\
\hline & $\mathrm{X}_{1.9}$ & 0,793 & 0,261 & 0,793 & Valid \\
\hline & $\begin{array}{l}1.9 \\
\mathrm{X}_{1.10}\end{array}$ & 0,680 & 0,261 & 0,680 & Valid \\
\hline \multirow{14}{*}{$\begin{array}{c}\text { Internal Resources } \\
\text { (X2) }\end{array}$} & $\mathrm{X}_{2.1}$ & 0,697 & 0,261 & 0,697 & Valid \\
\hline & $\mathrm{X}_{2.2}$ & 0,737 & 0,261 & 0,737 & Valid \\
\hline & $\mathrm{X}_{2,3}$ & 0,633 & 0,261 & 0,633 & Valid \\
\hline & $\mathrm{X}_{2.4}$ & 0,821 & 0,261 & 0,821 & Valid \\
\hline & $\mathrm{X}_{2.5}$ & 0,775 & 0,261 & 0,775 & Valid \\
\hline & $\mathrm{X}_{2.6}$ & 0,797 & 0,261 & 0,797 & Valid \\
\hline & $\mathrm{X}_{2.7}$ & 0,669 & 0,261 & 0,669 & Valid \\
\hline & $\mathrm{X}_{2.8}$ & 0,804 & 0,261 & 0,804 & Valid \\
\hline & $\mathrm{X}_{2.9}$ & 0,825 & 0,261 & 0,825 & Valid \\
\hline & $\mathrm{X}_{2.10}$ & 0,807 & 0,261 & 0,807 & Valid \\
\hline & $\begin{array}{l}2.210 \\
\mathrm{X}_{2.11}\end{array}$ & 0,787 & 0,261 & 0,787 & Valid \\
\hline & $\mathrm{X}_{2.12}$ & 0,819 & 0,261 & 0,819 & Valid \\
\hline & $\mathrm{X}_{2.13}$ & 0,655 & 0,261 & 0,655 & Valid \\
\hline & $\mathrm{X}_{2.14}$ & 0,810 & 0,261 & 0,810 & Valid \\
\hline
\end{tabular}

Source: Primary Data Processed, 2021

The test results of the UMKM Business Performance variable questionnaire with a total of 22 statements showed that all questionnaire items were declared valid $\left(r_{x y}>0.261\right)$. The items of the Entrepreneurship Orientation variable questionnaire with a total of 10 statements indicate that all questionnaire items are declared valid $\left(r_{x y}>0.261\right)$. Furthermore, the testing of internal resource variable 
questionnaire items with a total of 14 statements also showed that all questionnaire statement items were declared valid $\left(\mathrm{r}_{\mathrm{xy}}>0.261\right)$. Thus all questionnaire items are considered worthy to be used as instruments (tools) data collectors in this study.

Questionnaire reliability testing is conducted using the Alpha Cronbach method. Decision making related to the reliability or not the questionnaire item is determined based on the criteria of coefficient $r_{i} \geq$ 0.6 then the instrument or questionnaire is declared reliable (Arikunto, 2016).

Table 2. Questionnaire Reliability Test Results

\begin{tabular}{|c|c|c|c|c|}
\hline \multicolumn{5}{|c|}{ Overview } \\
\hline No & Variabele & $\begin{array}{c}\text { Coefficient } \\
r_{i}\end{array}$ & Criteria & Description \\
\hline 1. & $\begin{array}{l}\text { Business Performance of } \\
\text { MSMEs }(Y)\end{array}$ & 0,948 & $0,948>0,6$ & Reliabel \\
\hline 2. & Entrepreneurial Orientation $\left(X_{1}\right)$ & 0,890 & $0,890>0,6$ & Reliabel \\
\hline 3. & Internal Resources $\left(X_{2}\right)$ & 0,942 & $0,942>0,6$ & Reliabel \\
\hline
\end{tabular}

Source: Primary Data Processed, 2021.

Questionnaire reliability test results showed that the Alpha Cronbach value for all research variables was greater than 0.6. Alpha Cronbach value comparison for each questionnaire is a variable questionnaire of MSME Business Performance $(0.948>0.6)$; Entrepreneurship Orientation variable questionnaire $(0.890>0.6)$; Internal Resources variable questionnaire (0.942> 0.6). Thus, each questionnaire variable of this study is declared reliable so that it is feasible to be used as a data collection instrument in this study.

\section{Distribution of Questionnaire Score Frequency}

Respondents who were samples in this study numbered 55 people, namely the MSMEs home industry emping melinjo in The Corner Village. Based on the results of the dissemination of questionnaires to respondents will then be presented a description of the respondent's answer in the distribution of each questionnaire of research variables, namely Business Performance of MSMEs, Entrepreneurial Orientation, and Internal Resources.

a. Distribution of Frequency Of UMKM Business

Performance Variable Questionnaire Score (Y)

The frequency distribution table of MSMEs Business Performance (Y) variable questionnaire scores above explains the distribution of respondents answers to the statements on the variable questionnaire item UMKM business performance home industry emping melinjo in The Corner Village. Overall, the MSMEs Business Performance variable has an average score of 4.27. Following the criteria set based on the scale range, the variable Business Performance of MSMEs home industry emping melinjo in Pojok Village falls into the good category.

Table 3. Frequency Distribution of MSMEs Business Performance Variable Questionnaire Score (Y)

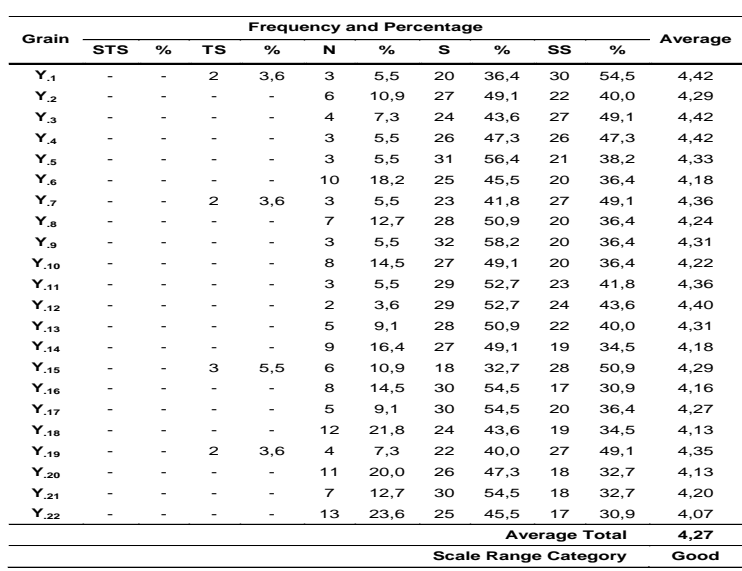

Source: Primary Data Processed, 2021

b. Distribusi Frekwensi Skor Kuisioner Variabel Orientasi Kewirausahaan $\left(\mathrm{X}_{1}\right)$

Table 4. Frequency Distribution of Entrepreneurial Orientation Variable Questionnaire Score $\left(\mathrm{X}_{1}\right)$

\begin{tabular}{|c|c|c|c|c|c|c|c|c|c|c|c|}
\hline \multirow{2}{*}{ Grain } & \multicolumn{10}{|c|}{ Frequency and Percentage } & \multirow{2}{*}{ Average } \\
\hline & STS & $\%$ & TS & $\%$ & $\mathbf{N}$ & $\%$ & $\mathrm{~S}$ & $\%$ & SS & $\%$ & \\
\hline $\mathrm{X}_{1.1}$ & - & 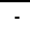 & 2 & 3,6 & 3 & 5,5 & 20 & 36,4 & 30 & 54,5 & 4,42 \\
\hline$X_{1.2}$ & - & - & - & - & 6 & 10,9 & 27 & 49,1 & 22 & 40,0 & 4,29 \\
\hline $\mathrm{X}_{1.3}$ & - & - & - & - & 4 & 7,3 & 24 & 43,6 & 27 & 49,1 & 4,42 \\
\hline$X_{1.4}$ & - & - & - & - & 3 & 5,5 & 26 & 47,3 & 26 & 47,3 & 4,42 \\
\hline $\mathrm{X}_{1.5}$ & - & - & - & - & 3 & 5,5 & 31 & 56,4 & 21 & 38,2 & 4,33 \\
\hline$X_{1.6}$ & - & - & - & - & 10 & 18,2 & 25 & 45,5 & 20 & 36,4 & 4,18 \\
\hline$X_{1.7}$ & - & - & 2 & 3,6 & 3 & 5,5 & 23 & 41,8 & 27 & 49,1 & 4,36 \\
\hline $\mathrm{X}_{1.8}$ & - & - & 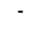 & - & 7 & 12,7 & 28 & 50,9 & 20 & 36,4 & 4,24 \\
\hline $\mathrm{X}_{1.9}$ & - & - & - & - & 3 & 5,5 & 32 & 58,2 & 20 & 36,4 & 4,31 \\
\hline $\mathrm{X}_{1.10}$ & - & - & 5 & 14,3 & 8 & 14,5 & 27 & 49,1 & 20 & 36,4 & 4,22 \\
\hline \multicolumn{11}{|c|}{ AverageTotal } & 4,32 \\
\hline \multicolumn{11}{|c|}{ Scale Range Category } & Good \\
\hline
\end{tabular}

Source: Primary Data Processed, 2021

The frequency distribution table of the Entrepreneurship Orientation variable questionnaire score $\left(\mathrm{X}_{1}\right)$ above explains the distribution of the respondents answer to the statements on the item of the Entrepreneurship Orientation variable questionnaire of the UMKM home industry emping melinjo in The Corner Village. Overall, the Entrepreneurial Orientation variable has an average score of 4.32. Under the criteria of the scale range, the variable Orientation of Entrepreneurship of msmes home industry emping melinjo in The Corner Village belongs to the good category.

c. frequency Distribution of Internal Resource Variable Questionnaire Scores $\left(\mathrm{X}_{2}\right)$ 
Table 5. Frequency Distribution of Internal Resource Variable Questionnaire Scores $\left(\mathrm{X}_{2}\right)$

\begin{tabular}{|c|c|c|c|c|c|c|c|c|c|c|c|}
\hline \multirow{2}{*}{ Grain } & \multicolumn{10}{|c|}{ Frequency and Percentage } & \multirow{2}{*}{ Average } \\
\hline & STS & $\%$ & TS & $\%$ & $\mathbf{N}$ & $\%$ & $\mathrm{~s}$ & $\%$ & SS & $\%$ & \\
\hline$X_{2.1}$ & - & - & - & - & 9 & 16,4 & 21 & 38,2 & 25 & 45,5 & 4,29 \\
\hline $\mathrm{X}_{2.2}$ & - & - & - & - & 4 & 7,3 & 29 & 52,7 & 22 & 40,0 & 4,33 \\
\hline$X_{2.3}$ & - & - & - & - & 8 & 14,5 & 20 & 36,4 & 27 & 49,1 & 4,35 \\
\hline$X_{2.4}$ & - & - & - & - & 7 & 12,7 & 24 & 43,6 & 24 & 43,6 & 4,31 \\
\hline$X_{2.5}$ & - & - & - & - & 3 & 5,5 & 29 & 52,7 & 23 & 41,8 & 4,36 \\
\hline $\mathrm{X}_{2.6}$ & - & - & - & - & 11 & 20,0 & 21 & 38,2 & 23 & 41,8 & 4,22 \\
\hline$X_{2.7}$ & - & - & 2 & 3,6 & 3 & 5,5 & 23 & 41,8 & 27 & 49,1 & 4,36 \\
\hline $\mathrm{X}_{2.8}$ & - & - & - & - & 9 & 16,4 & 27 & 49,1 & 19 & 34,5 & 4,18 \\
\hline$X_{2.9}$ & - & - & - & - & 5 & 9,1 & 28 & 50,9 & 22 & 40,0 & 4,31 \\
\hline$X_{2.10}$ & - & - & - & - & 9 & 16,4 & 27 & 49,1 & 19 & 34,5 & 4,18 \\
\hline$X_{2.11}$ & - & - & - & - & 4 & 7,3 & 29 & 52,7 & 22 & 40,0 & 4,33 \\
\hline$X_{2.12}$ & - & - & - & - & 6 & 10,9 & 24 & 43,6 & 25 & 45,5 & 4,35 \\
\hline$X_{2.13}$ & - & - & - & - & 4 & 7,3 & 24 & 43,6 & 27 & 49,1 & 4,42 \\
\hline \multirow[t]{2}{*}{$X_{2.14}$} & - & - & - & - & 12 & 21,8 & 22 & 40,0 & 21 & 38,2 & 4,16 \\
\hline & & & & & & & & \multicolumn{3}{|c|}{ AverageTotal } & $\begin{array}{c}4,30 \\
\text { Good }\end{array}$ \\
\hline
\end{tabular}

Source: Primary Data Processed, 2021

Overall, the Internal Resources variable has an average score of 4.30. Following the criteria of the scale range, internal resources variables owned by MSMEs home industry emping melinjo in The Corner Village is included in the good category. This provides an understanding that the average MSMEs have good and adequate internal resources when measured based on aspects of financial capital, physical capital, human capital, technology capital, and organizational capital. The rest of MSMEs also have competitive advantages as criteria VRIN (Valuable, Rare, Imperfect Imitability, and NonSubstitution).

\section{Data Analysis}

The data analysis in this study was conducted based on the conception of inferential statistics that were later used to test the research hypothesis. The data analysis in this study uses multiple linear regression methods which will be followed by hypothesis testing using F-test and t-test.

\section{a) Descriptive analysis results}

Descriptive statistics in this study include minimum and maximum values, mean, and standard deviation (std. deviation) of each MSMEs Business Performance variable (Y), Entrepreneurship Orientation variable $\left(\mathrm{X}_{1}\right)$ and Internal Resource variable $\left(\mathrm{X}_{2}\right)$.

The results of the analysis showed a mean value of 94.04 with a standard deviation of 10.35 . The mean value is greater than the standard deviation which means it represents good data because the average variable data of MSMEs Business Performance has a low deviation rate or data is homogeneous (evenly distributed). if the standard deviation value is greater than the mean means that the data distribution varies (heterogeneous) or the average data has a high degree of deviation so that the data is abnormal.

Table 6. Overview of Descriptive Statistical Calculation Results.

\begin{tabular}{|l|c|c|c|}
\hline \multicolumn{4}{|c|}{ Statistics } \\
\hline & $\begin{array}{c}\text { Entrepreneurial } \\
\text { Orientation }\left(\mathbf{X}_{1}\right)\end{array}$ & $\begin{array}{c}\text { Internal } \\
\text { Resources } \\
\left(\mathbf{X}_{2}\right)\end{array}$ & $\begin{array}{c}\text { Business } \\
\text { Performance } \\
\text { of MSMEs }(Y)\end{array}$ \\
\hline $\mathbf{N} \quad$ Valid & 55 & 55 & 55 \\
Mean Missing & 0 & 0 & 0 \\
Std. Deviation & 43.18 & 60.15 & 94.04 \\
Minimum & 4.722 & 7.266 & 10.358 \\
Maximum & 31 & 41 & 70 \\
Sum & 49 & 70 & 109 \\
\hline
\end{tabular}

Source. Research analysis results (2021)

MSMEs Business Performance Variable (Y)

Entrepreneurial Orientation Variable $\left(\mathrm{X}_{1}\right)$

The results of the analysis showed a mean value of 43.18 with a standard deviation of 4.72 . The mean value is greater than the standard deviation that represents this variable data either because the average data of the Entrepreneurial Orientation variable has a low deviation rate or the data is homogeneous (evenly distributed).

Internal Resource Variables $\left(\mathrm{X}_{2}\right)$

The results of the analysis showed that the mean value was 60.15 with a standard deviation of 7.26. The mean value is greater than the standard deviation that represents internal resource variable data either because the average data has a low deviation rate or the data is homogeneous (evenly distributed).

\section{b) Classic Assumption Test Results Normality Test}

A good regression model is if all research variables have data that is normally distributed or close to normal. The data normality test in this study was conducted using a Kolmogorov-Smirnov test. The basis of decision making on the normal or not of research data according to Ghozali (2016) is determined based on criteria if the value of Asymp. $\mathrm{Sig}$. greater than the level of significance $(\mathrm{p}>0.05)$ then the data is normally distributed. The results of the Kolmogorov-Smirnov normality test can be seen in the following table.

Table 7. Kolmogorov-Smirnov Test Result Output

\begin{tabular}{|c|c|c|}
\hline & & $\begin{array}{c}\text { Unstandardized } \\
\text { Residual }\end{array}$ \\
\hline N & & 55 \\
\hline \multirow[t]{2}{*}{ Normal Parameters ${ }^{a, b}$} & Mean & OE-7 \\
\hline & Std. Deviation & 1.28554723 \\
\hline \multirow[t]{3}{*}{ Most Extreme Differences } & Absolute & .094 \\
\hline & Positive & .094 \\
\hline & Negative & -.063 \\
\hline Kolmogorov-Smirnov Z & & .701 \\
\hline Asymp. Sig. (2-tailed) & & .710 \\
\hline
\end{tabular}

Source. Research analysis results (2021) 
The results of the normality test data using the Kolmogorov-Smirnov test as in the coefficients output showed the value of Asymp. Gis is smaller than significance $(0.710>0.05)$. Thus it can be concluded that the research data is normally distributed so that this will result in a good regression model.

\section{Heteroskedasticity Test}

The Heteroskedasticity test is conducted using the Glejser test. The working principle of the heteroskedasticity test using the Glejser test in this study is by regressing the free variables of Entrepreneurial Orientation $\left(\mathrm{X}_{1}\right)$ and Internal Resources $\left(\mathrm{X}_{2}\right)$ against residual Absolute values or Abs_RES. The basis of Glejser's test decisionmaking is that if the value of significance (sig.) is smaller than 0.05, then the conclusion is that heteroskedasticity symptoms occur in regression models or homogeneous data (Ghozali, 2016). Glejser test results can be seen in the table below.

Table 8. Glesjer Test Result Output

Coefficients $^{2}$

\begin{tabular}{|c|c|c|c|c|c|}
\hline \multirow[b]{2}{*}{ Model } & \multicolumn{2}{|c|}{$\begin{array}{l}\text { Unstandardized } \\
\text { Coefficients }\end{array}$} & \multirow{2}{*}{$\begin{array}{c}\text { Standard ized } \\
\text { Coefficients }\end{array}$} & & \multirow{3}{*}{ Sig } \\
\hline & B & Std.Error & & & \\
\hline $\begin{array}{ll}\text { l } & \text { (Costant) }\end{array}$ & 1.208 & .921 & & 1.312 & \\
\hline $\begin{array}{l}\text { Entrep reneurial } \\
\text { Orientation }\left(\mathrm{X}_{1}\right)\end{array}$ & .151 & 100 & 1.019 & 1.516 & 136 \\
\hline Resources $\left(\mathrm{X}_{2}\right)$ & .111 & .065 & -1.150 & -1.710 & .093 \\
\hline
\end{tabular}

Source. Research analysis results (2021)

Heteroskedastisitas test results with Glejser Test as in coefficients output with variables bound Abs_RES to act as dependent variables. The output of the calculation shows that the significance value (sig.) of the Entrepreneurial Orientation variable $\left(\mathrm{X}_{1}\right)$ is 0.136 and the significance value (sig.) of the Internal Resource variable $\left(\mathrm{X}_{2}\right)$ is 0.093 . The significance values (sig.) on both free variables are smaller than 0.05 (sig. > 0.05). Thus it can be concluded that the research data does not occur symptoms of heteroskedasticity or homogeneous so that the data will produce a good regression model.

\section{Multicolonierity Test}

A good regression model if there is no relationship between independent variables, which in this case is the relationship between the Entrepreneurial Orientation variable $\left(\mathrm{X}_{1}\right)$ and the Internal Resource variable $\left(\mathrm{X}_{2}\right)$. Decision making is made with criteria if the tolerance value $\leq 1$ means there is no correlation between independent variables and if the VIF does not exceed 10 then the model is declared not exposed to multicollinearity problems. An overview of multicollinearity test results can be seen in the table below.
Table 9. Multicollinearity Test Results Coefficients $^{\mathrm{a}}$

\begin{tabular}{|c|c|c|c|c|c|c|}
\hline \multirow[b]{2}{*}{ Model } & & \multicolumn{2}{|c|}{$\begin{array}{l}\text { Unstandardized } \\
\text { Coefficients }\end{array}$} & \multirow{2}{*}{\begin{tabular}{|c}
$\begin{array}{c}\text { Standardized } \\
\text { Coefficients }\end{array}$ \\
Beta \\
\end{tabular}} & \multicolumn{2}{|c|}{ Collinearity Statistich } \\
\hline & & B & Std. Error & & Tolerance & VIF \\
\hline 1 & $\begin{array}{l}\text { (Costant) } \\
\text { Entrepreneurial }\end{array}$ & 6.952 & 1.749 & .193 & .040 & 7.511 \\
\hline & $\begin{array}{l}\text { Orientation }\left(\mathrm{X}_{1}\right) \\
\text { Internal Resources }\end{array}$ & .424 & .189 & .802 & .040 & 7.511 \\
\hline & $\left(X_{2}\right)$ & 1.144 & 123 & & & \\
\hline
\end{tabular}

Source. Research analysis results (2021)

The results of tolerance and VIF calculations show that the Entrepreneurship Orientation variable $\left(X_{1}\right)$ and internal resource variable $\left(X_{2}\right)$ have a tolerance value of 0.040 and a VIF value of 7.511 , respectively. This indicates that the regression model does not experience symptoms of multicolumn because each variable has no tolerance value exceeding 1 and no VIF value exceeds 10 Thus the proposed model is free from deviations from the assumption that the classic model of data multicollinearity will result in a good regression model.

\section{c) Multiple Linear Regression Test Results}

The multiple linear regression analysis in this study is intended to measure the significance of the influence of Entrepreneurship Orientation free variables $\left(\mathrm{X}_{1}\right)$ and Internal Resource variables $\left(\mathrm{X}_{2}\right)$ on MSME (Y) business performance bound variables. An overview of the results of multiple linear regression calculations can be seen below.

Table 10. Multiple Linear Regression Test Result Output Coefficients ${ }^{2}$

\begin{tabular}{|c|c|c|c|c|c|c|}
\hline \multirow[b]{2}{*}{ Model } & & \multicolumn{2}{|c|}{$\begin{array}{l}\text { Unstandardized } \\
\text { Coefficients }\end{array}$} & \multirow{2}{*}{$\begin{array}{c}\begin{array}{c}\text { Standardized } \\
\text { Coefficients }\end{array} \\
\text { Beta }\end{array}$} & \multirow[b]{2}{*}{$t$} & \multirow[b]{2}{*}{ Sig } \\
\hline & & B & Std. Error & & & \\
\hline 1 & (Costant) & 6.952 & 1.749 & 193 & 3.974 & .000 \\
\hline & Entrepreneurial & & & & & \\
\hline & Orientation $\left(X_{1}\right)$ & .424 & .189 & .802 & 2.241 & .029 \\
\hline & $\begin{array}{l}\text { Internal Resources } \\
\left(\mathrm{X}_{2}\right)\end{array}$ & 1.144 & .123 & & 9.301 & .000 \\
\hline
\end{tabular}

Source. Research analysis results (2021)

The output of the double linear regression analysis test above explains that the multiple linear regression models that are built are as follows: $\mathrm{Y}=$ $6.952+0.424 \mathrm{X}_{1}+1.144 \mathrm{X}_{2}$. This multiple linear regression equation explains the following:

- A constant of 6,952 indicates that if there is no Entrepreneurship Orientation $\left(\mathrm{X}_{1}\right)$ and Internal Resources $\left(\mathrm{X}_{2}\right)$ variable then the MSMEs Business Performance (Y) variable is worth 6,952.

- The Entrepreneurship Orientation $\left(\mathrm{X}_{1}\right)$ variable regression coefficient is positive at 0.424 . This provides an understanding that each unit of Entrepreneurship Orientation $\left(\mathrm{X}_{1}\right)$ will affect the improvement of MSMEs Business Performance 
0.424 assuming the Internal Resource variable $\left(\mathrm{X}_{2}\right)$ is fixed or constant (zero).

- The Coefficient of Internal Resource variable regression $\left(\mathrm{X}_{2}\right)$ is positive at 1,144 . This provides an understanding that each unit of Internal Resources $\left(\mathrm{X}_{2}\right)$ will affect the improvement of MSMEs Business Performance by 1,144 assuming the variable Entrepreneurship Orientation $\left(\mathrm{X}_{1}\right)$ is fixed or constant (zero).

\section{d). Determination Coefficient Test Result $\left(\mathbf{R}^{2}\right)$}

The coefficient of determination $\left(\mathrm{R}^{2}\right)$ in multiple linear regression analysis has meaning as a contribution or contribution of influence given by the free variable Entrepreneurship Orientation $\left(X_{1}\right)$ and internal resource variable $\left(X_{2}\right)$ to the variable bound by MSME Business Performance (Y). The calculation result of the Determination Coefficient $\left(R_{2}\right)$ can be seen below.

Table 11. Result Output Coefficient of Determination (R2)

Model Summary ${ }^{\mathrm{b}}$

\begin{tabular}{rl|r|r|r|r|}
\hline Model & $R$ & R Square & $\begin{array}{c}\text { Adjusted R } \\
\text { Square }\end{array}$ & $\begin{array}{c}\text { Std. Error of } \\
\text { the Estimate }\end{array}$ \\
\hline 1 & $.992^{\mathrm{d}}$ & .985 & .984 & 1.310 \\
\hline
\end{tabular}

Source. Research analysis results (2021)

The calculation result of The Determination Coefficient $\left(\mathrm{R}^{2}\right)$ as the SPSS output above shows that both adjusted coefficients R-squared $\left(\mathrm{R}^{2}\right)$ amounted to 0.984 . This gives the sense that the contribution or contribution of free variables of Entrepreneurship Orientation $\left(\mathrm{X}_{1}\right)$ and Internal Resource variables $\left(\mathrm{X}_{2}\right)$ to variables bound by MSMEs Business Performance (Y) was 98.4\%, while the remaining $1.6 \%$ was influenced by other variables not measured in this study.

\section{e). Hypothesis Test Results Hypothesis I Test Results}

Hypothesis I: It is suspected that there is a significant influence simultaneously on entrepreneurial orientation and internal resources on the business performance of MSMEs home industry emping melinjo in Pojok Village.
Table 12. Output Results F-test

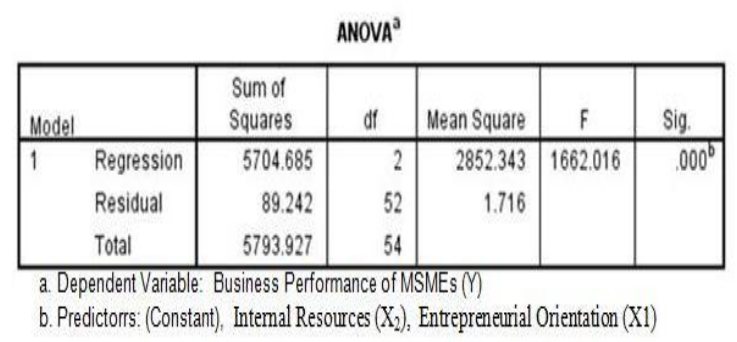

Source. Research analysis results (2021)

The F-test result as in the SPSS output above shows that the significance value of $\mathrm{F}$ (sig.) is 0.000 or less than the level of significance $(\alpha)$ $(0.000<0.05)$. This indicates the simultaneous significant influence of Entrepreneurship Orientation $\left(\mathrm{X}_{1}\right)$ and Internal Resources $\left(\mathrm{X}_{2}\right)$ free variables on MSMEs (Y) business performance bound variables. Thus, the research hypothesis that reads allegedly there is a significant influence simultaneously entrepreneurial orientation and internal resources on the business performance of MSMEs home industry emping melinjo in The Corner Village, Ngantru Subdistrict, Tulungagung Regency can be accepted or tested for truth.

\section{Hypothesis II and III Test Results}

Hypotheses II and III in this study mentioned that each is suspected to have a partially significant influence on the business performance of MSMEs home industry emping melinjo in Pojok Village. The test was conducted using t-test significance test at the level of significance $(\alpha)=5 \%$. Decision making on the partial influence of free variables on bound variables is done by comparing the value of significance $t$ ( $\operatorname{sig}$.) with the level of significance $(\alpha)$. If the significance value of $\mathrm{t}$ (sig.) is smaller than the level of significance $(\alpha)$ then partially the free variable has a significant effect on the bound variable (Ghozali, 2016). The results of t-test calculation can be seen in the SPSS output below.

Table 13. Output Result t-test Coefficients $^{\mathrm{a}}$

\begin{tabular}{|ll|r|r|}
\hline Model & \multicolumn{1}{|c|}{ t } & Sig. \\
\hline 1 & (Constant) & 3.974 & .000 \\
& Entrepreneurial Orientation $\left(\mathrm{X}_{1}\right)$ & 2.241 & .029 \\
& Internal Resources $\left(\mathrm{X}_{2}\right)$ & 9.301 & .000 \\
\hline \multicolumn{2}{|c}{} \\
\multicolumn{2}{|c|}{ a. Dependent Variable: Business Performance of MSMEs $(\mathrm{Y})$}
\end{tabular}

Source. Research analysis results (2021)

\section{Hypothetical Test Result II}

Hypothetical Test Result II: It is suspected that there is a significant influence of entrepreneurial 
orientation on the business performance of MSMEs home industry emping melinjo in The Corner Village.

The test result of t-test states the probability value of $t$ (sig.) is less than the level of significance $(0.029<0.05)$. This shows there is a positive and significant influence of variable Entrepreneurship Orientation $\left(\mathrm{X}_{1}\right)$ on the Business Performance of MSMEs (Y). Thus, the research hypothesis that reads allegedly there is a significant influence of entrepreneurial orientation on the business performance of MSMEs home industry emping melinjo in The Corner Village, Ngantru Subdistrict, Tulungagung Regency can be accepted or tested for truth.

\section{Hypothesis III Test Results}

Hypothesis III: it is suspected that there is a significant influence of internal resources on the business performance of MSMEs home industry emping melinjo in Pojok Village.

The test result of t-test states the probability value of $\mathrm{t}$ (sig.) is less than the level of significance $(0.000<0.05)$. This confirms there is a significant influence of Internal Resource variables (X2) on the Business Performance of MSMEs (Y). Thus, the research hypothesis that reads allegedly there is a significant influence of internal resources on the business performance of MSMEs home industry emping melinjo in The Corner Village, Ngantru Subdistrict, Tulungagung Regency can be accepted or tested for truth.

\section{The Influence of Entrepreneurship Orientation and Internal Resources on MSME Business Performance}

Business performance measurement should use a balanced scorecard, which is a performance gauge that measures the company's overall performance both financially and non-financially (Anthony et al, 2009). A balanced scorecard as a performance gauge itself was originally developed by Kaplan and Norton (2006) as part of the management concept in the form of the concept of measuring the company's performance. Therefore, THE business performance of MSMEs is measured by using a balanced scorecard based on financial perspective, customer perspective, internal business process perspective, and learning and growth perspective (Kaplan and Norton, 2006; Mulyadi, 2011).

Some things that need to be considered by MSMEs to improve the business performance of MSMEs is to always stick to the principles of entrepreneurial-oriented business and optimize the internal resources owned by MSMEs. Entrepreneurial orientation is the process, practice, and decision-making activities or tendency of individuals to innovate, be proactive, and be willing to take risks to start or manage businesses that are the basis, and resources to find business opportunities to succeed. Meanwhile, internal resources are the ownership of various assets internally which is the source of the power of MSMEs to run businesses to achieve profit.

The results of this study mentioned that there is a significant influence simultaneously on entrepreneurial orientation and internal resources on the business performance of MSMEs home industry emping melinjo in Pojok Village, Ngantru Subdistrict, Tulungagung Regency. The results of this study are in line with the results of Basile research (2012) which researched with small and medium enterprises (SMEs) in Italy. The results of this study concluded that entrepreneurial orientation, internal resources, and external resources have a significant effect both simultaneously on the performance of SMEs in Italy. The results of this study are also consistent with the results of Witjaksono research (2014) which confirms that entrepreneurial orientation and internal resources have a significant positive effect on the company's performance, either directly or indirectly through competitive advantage.

\section{The Influence of Entrepreneurship Orientation on The Business Performance of MSMEs.}

Entrepreneurial orientation is the process, practice, and decision-making activities or tendency of individuals to innovate, be proactive and willing to take risks to start or manage businesses that serve as the basis and resources to find opportunities for success. At the heart of entrepreneurship is the ability to create something new and different through creative thinking and innovative acting to create opportunities. Related to this, the entrepreneurial orientation in question is the entrepreneurial orientation owned by MSMEs which is measured based on aspects of innovativeness, risk-taking, proactiveness, competitive aggressiveness, and autonomy (Lumpkin and Dess, 2006).

The results of this study mentioned that there is a significant influence of entrepreneurial orientation on the business performance of MSMEs home industry emping melinjo in The Corner Village, Ngantru Subdistrict, Tulungagung Regency. The results of this study are in line with the results of the study that concluded the positive and significant influence of entrepreneurial orientation on business performance and some of the business performance is the business performance of MSMEs.

The results of the study are in line with the opinion that there is a significant relationship between entrepreneurial orientation and corporate performance (Gosselin, 2005), entrepreneurial orientation is one of the company's resources and capabilities (Ferreria and Azevedo, 2008). An 
increasingly good entrepreneurial orientation will be able to improve the company's ability to market its production towards better business performance (Wiklund, 2009). Entrepreneurial orientation is related to the search for opportunities, the courage to take risks and the decisions of the organization's leaders. This will have a direct impact on the company's business performance results (Knight, 2000:14).

Entrepreneurial orientation is a very important component in developing a business. Entrepreneurial orientation is believed to boost the performance of MSMEs in developing the products produced. Higher entrepreneurial orientation can improve the company's ability to market its products towards better business performance (Covin and Slevin, 1991). Entrepreneurship orientation is a very important component in the development efforts of MSMEs. Without a directed orientation, MSMEs will be difficult to win the competition in contesting the market.

\section{Effect of Internal Resources on MSME Business Performance.}

The results of this study mentioned that there is a significant influence of internal resources on the business performance of MSMEs home industry emping melinjo in Pojok Village. The results of this study are in line with the results of research conducted by Basile (2012) and Witjaksono research results (2014) which each concluded in his research that there is a significant influence of internal resources on business performance, some of which are the business performance of MSMEs.

The results of the study are in line with the opinion that companies, including MSMEs, have some support in the form of resources that will greatly affect the success of the company's business performance (MSMEs) itself. Business growth and performance are influenced by several factors that are classified into 2 (two) categories, namely factors related to the internal business environment and factors related to the external business environment. Both internal and external resource factors will greatly affect the company's business performance which leads to the company's success. In the context of internal resources, businesses with good financial management capabilities will experience higher revenue increases compared to businesses that are not supported by good financial management capabilities (Capps and Glissmeyer, 2012).

Resource-Based Strategy states that attention to the use of internal resources as a business strategy to face the success of the product creation process should be developed for the entire manufacturing business through a strategy based on superior internal resource development (Mosakowski, 2015). The resource-based view of firms states that certain types of resources owned and controlled by companies have the potential to generate competitive advantages that ultimately deliver superior business performance. The relationship between resources and competitive advantage is strongly influenced by elements such as assets owned by the company that can be interpreted as one of the strengths in supporting the company's business performance (Rose et al., 2010). Manufacturing businesses will get easy guidance in conducting evaluations based on the strengths and weaknesses of existing internal resource capabilities. The results of this evaluation will be used in decision making to improve the company's business performance (Lovas and Ghoshal, 2010). This provides an understanding that the development of internal resources in a good and optimal manner will ensure the success of the company's business performance (MSMEs).

\section{CONCLUSION}

There is a significant influence simultaneously on entrepreneurial orientation and internal resources on the business performance of MSMEs home industry emping melinjo in Pojok Village, Ngantru Subdistrict, Tulungagung Regency.

There is a significant influence of entrepreneurial orientation on the business performance of MSMEs home industry emping melinjo in The Corner Village, Ngantru Subdistrict, Tulungagung Regency.

There is a significant influence of internal resources on the business performance of MSMEs home industry emping melinjo in Pojok Village, Ngantru Subdistrict, Tulungagung Regency.

\section{SUGGESTIONS}

1. Office of Cooperatives and MSMEs

- Should pay special attention in the form of training and management assistance to improve the business performance of MSMEs because it is proven that MSMEs have a role in supporting the regional economy while reducing the unemployment rate.

- Should help provide solutions in addressing the problems faced by MSMEs, such as capital, reduced labour, access to raw material supplies, marketing distribution, and so on.

\section{MSMEs Actors}

- Should always strive to improve the business performance of MSMEs to be able to compete with similar MSMEs while being able to win the market competition.

- It should be done in the management of MSMEs with entrepreneurial orientation because it is proven that entrepreneurial orientation has a significant influence on the business performance of MSMEs. This can be done by 
always trying to improve aspects of intimates, courage in risk-taking, activeness, aggressiveness in competing, and autonomy (self-reliance).

3. Next researcher

Should make the results of this study a reference in conducting further research and development research. Research can be done with different variables, different objects, and different analytical methods.

\section{REFERENCES}

Anthony et al.(2009). Akutansi Manajemen. edisi 5. Jilid 1. Terjemahan oleh Miranti Kartika Dewi. Jakarta: PT. Indeks

Arikunto, S. (2016). Prosedur Penelitian Suatu Pendekatan Praktik. Jakarta : Rineka Cipta

Basile, A. (2012). Entrepreneurial Orientation in Smes: Risk-Taking To Entering International Markets, Journal Far East Journal of Psychology and Business, Vol. 7. p. 87-103

Capps, III, C. J., \& Glissmeyer, M. D. (2012). Extending The Competitive Profile Matrix Using Internal Factor Evaluation And External Factor Evaluation Matrix Concepts. Journal of Applied Business Research (JABR), 28(5), 1059-1062. https://doi.org/10.19030/jabr.v28i5.7245

Covin, J.G. \& Slevin, D.P. (1991). A conceptual model of entrepreneurship as firm behavior. Entrepreneurship Theory and Practice, Fall, 725.

Ferreria, J. \& Azevedo, S.G. (2008). Entrepreneurial orientation and growth of firms: Key lessons for managers and business professionals. Problems and Perspectives in Management, 6(1), 82-88.

Ginsberg, A. (2011). "Measuring Changes in Entrepreneurial Orientation Following Industry Deregulation: The Development of a Diagnostic Instrument," Proceedings of International Council of Small Business.

Gosselin, M (2005). An Empirical Study of Performance Measurement in Manufacturing Firm,'International Journal of Productivity and Performance Management, Volume 54, Number 5, 419-437
Ghozali. (2016). Aplikasi Analisis Multivariete Dengan Program IBM SPSS. Semarang: Badan Penerbit Universitas Diponegoro.

Kaplan dan Norton, (2006). Lingking the Balance Scorecard to Strategy, Manajemen Review Vol.39 No.1, California.

Kuncoro, W \& Suriani, W. O. (2018). Achieving sustainable competitive advantage through product innovation and market driving. Asia Pacific Management Review, 23(3), 186-192.

Knight, G. (2000). Entrepreneurship and Marketing Strategy: the SME Under Globalization. Journal of International Marketing, ISSN 1069-031X, Vol.8, No.2

Lumpkin, G. T., \& Dess, G. G. (2006). The effect of 'simplicity'on the strategy performance relationship: A note. Journal of Management Studies, 43(7), 1583-1604.

Lovas, B. and Ghoshal, S. (2010). Strategy as Guided Evolution. Strategic Management Journal 21(9):875-96.

Mulyadi, (2011). Sistem Akuntansi. Yogyakarta: Salemba Empat.

Witjaksono,. (2014). Analisis Orientasi Kewirausahaan dan Sumber Daya Internal Perusahaan terhadap Kinerja melalui Keunggulan Bersaing (Studi pada Usaha Mikro Kecil dan Menengah Furniture Kabupaten Jepara). Jurnal Bisnis Strategi Vol.23 No. 1

Risnawati dan Noermijati. (2008). Pengaruh Orientasi Kewirausahaan terhadap Kinerja Organisasi Koperasi : Orientasi Pasar sebagai Variabel Intervening (Studi pada Koperasi Primer di kota Palu, Sulawesi Tengah) dalam Jurnal Aplikasi Manajemen Vol 9. No.3.

Rauch, A., Wiklund, J., Lumpkin, G. T., \& Frese, M. (2009). Entrepreneurial orientation and business performance: An assessment of past research and suggestions for the future. Entrepreneurship theory and practice, 33(3), 761-787.

Rose, Raduan Che, Haslinda Abdullah, dan Alimin Ismail Ismad. (2010). A Review on the Relationship Between Organizational Resources, Competitive Advantage and Performance. The Journal of International Social Research, Volume 3/11, Spring. 
This page is intentionally left blank 